\title{
STANDING TO HOLD RESPONSIBLE
}

\begin{abstract}
We often hold others responsible, and are held responsible ourselves. Many philosophers claim that to evaluate such holdings, we must consider the standing of the holder. Many also claim that both hypocrites and meddlers lack standing. Little has been said, however, about what exactly standing is-about what it is that hypocrites and meddlers are supposed to lack. Though talk of standing is now widespread, 'we do not', in Joseph Raz's words, 'have an unproblematic grasp of the phenomena referred to' by such talk. In this paper I attempt to improve that grasp. I offer an account of what it is to have, and lack, standing to hold others responsible. And I offer some reasons why, if this account is accepted, both hypocrites and meddlers should lack standing.
\end{abstract}

Keywords_-Accountability; Blame; Responsibility; Standing

We often hold others responsible, and are held responsible ourselves. We call one another to account. We condemn, criticise and blame. Perhaps we could do without all this. But it is part of our everyday lives as they are now. Many claim that to evaluate such holdings, we must consider the standing of the holder. According to Antony Duff,

To show that [someone] is being legitimately called to account, we must show not just that there is something for which he should have to answer, but that those who call him have the standing to do so. ${ }^{1}$

Similar claims are made about condemnation, criticism and blame. G.A. Cohen writes that 'a person may seek to silence' the condemnation of a critic by seeking to 'discredit her critic's assertion of her standing' to condemn. ${ }^{2}$ T.M. Scanlon suggests that when 'a person's standing to blame' is 'undermined' that person is 'not in a position' to do the

\footnotetext{
${ }^{1}$ Antony Duff, 'Responsibility, Citizenship and Criminal Law', in R.A. Duff and S.P. Green (eds.), Philosophical Foundations of Criminal Law (Oxford: Oxford University Press, 2011), p. 132.

${ }^{2}$ G.A. Cohen, 'Casting the First Stone: Who Can, and Who Can't, Condemn the Terrorists?', in G.A. Cohen, Finding Oneself in the Other (Princeton: Princeton University Press, 2013), p. 119.
} 
blaming. ${ }^{3}$ And R. Jay Wallace argues that 'the fundamental moral objection' to certain acts of criticism is that the critics 'are engaged in an activity' in which 'they lack the standing to engage. ${ }^{4}$

No doubt there are important differences between these ways of holding others responsible. Talk of standing has, however, come to pervade philosophical discussion of each. ${ }^{5}$ What is surprising is how little has been said about what exactly standing is. It is clear enough that a holding is in some way defective if the holder lacks standing. It is much less clear what the defect in question amounts to. One reason for the lack of clarity is that, while the idea of standing is often used, it is rarely subjected to explicit analysis. Many who talk of standing focus not on the idea itself, but on particular cases in which it is thought to be absent, and on what is thought to ground this absence. Cohen, Scanlon, Wallace and others discuss cases of hypocrisy, in which holders engage in the kind of conduct for which they hold others responsible. ${ }^{6}$ Duff, Linda Radzik, Angela Smith and others discuss cases of meddling, in which holders fail to mind their own business by doing the holding. Each writer claims that hypocrites and meddlers lack standing. Each has interesting things to say about why this might be. But when it comes to what exactly

\footnotetext{
3 T.M. Scanlon, Moral Dimensions: Permissibility, Meaning, Blame (Cambridge: Harvard University Press, 2008), p. 175.

${ }^{4}$ R. Jay Wallace, 'Hypocrisy, Moral Address and the Equal Standing of Persons', Philosophy and Public Affairs 38 (2010), p. 317.

${ }^{5}$ See, among others: Angela Smith, 'On Being and Holding Responsible', Journal of Ethics 11 (2007), pp. 478-480; Victor Tadros, 'Poverty and Criminal Responsibility', Journal of Value Inquiry 43 (2009), pp. 391 413; Antony Duff, 'Blame, Moral Standing and the Legitimacy of the Criminal Trial', Ratio 23 (2010), pp. 123-140; Linda Radzik, 'On the Virtue of Minding Our Own Business', Journal of Value Inquiry 46 (2012), pp. 173-182; Garrath Williams, 'Sharing Responsibility and Holding Responsible', Journal of Applied Philosophy 30 (2013), pp. 351-364; Gary Watson, 'A Moral Predicament in the Criminal Law', Inquiry 58 (2015), pp. 168-188; N.A. Tognazzini and J.D. Coates, 'Blame', in E.N. Zalta (ed.), The Stanford Encyclopedia of Philosophy (Spring 2016), <http://plato.stanford.edu/archives/spr2016/entries/blame/>.

${ }^{6}$ This is a rough characterisation. Later, I make it more precise.
} 
hypocrites and meddlers lack, each offers only a few brief remarks. Cohen sometimes suggests that to lack standing is to suffer from a disability, ${ }^{7}$ and sometimes that it is to lack a right. ${ }^{8}$ But he admits to not having 'produced an explication that specifies, with satisfying precision, and in general terms, the nature of the defect' in which a lack of standing consists. ' Scanlon writes of a 'bar' to blame, ${ }^{10}$ and Wallace of being deprived of an 'entitlement' to criticise. ${ }^{11}$ But neither says much more than that. Like other writers, Duff sometimes appears to equate standing with authority. ${ }^{12}$ Elsewhere, however, he distinguishes the two. ${ }^{13}$ Radzik suggests that those who lack standing can be ignored by those they hold responsible, ${ }^{14}$ while Smith writes that when we lack standing it is 'not our place' to do the holding. ${ }^{15}$

Though these comments are suggestive, they are little more than that. Nor is it obvious that the suggestions are all of a piece. As Joseph Raz has observed, though many writers talk of standing, 'we do not have an unproblematic grasp of the phenomena referred to' by such talk. ${ }^{16}$ And our grasp is not unimportant. The practice of holding others

\footnotetext{
${ }^{7}$ Cohen, Finding Oneself, pp. 119, 123.

${ }^{8}$ Cohen, Finding Oneself, p. 120.

${ }^{9}$ Cohen, Finding Oneself, p. 121.

${ }^{10}$ Scanlon, Moral Dimensions, p. 177.

11 Wallace, 'Hypocrisy, Moral Address and the Equal Standing of Persons', pp. 316-317.

12 Antony Duff, 'Relational Reasons and the Criminal Law', in L. Green and B. Leiter (eds.) Oxford Studies in Philosophy of Law: Vol 2 (Oxford: Oxford University Press, 2013), p. 196. This equation can also be found in: Gerald Postema, 'Politics is About the Grievance', Legal Theory 11 (2005), p. 303; Stephen Darwall, 'Authority and Reasons: Exclusionary and Second-Personal', Ethics 120 (2010), p. 262; Williams, 'Sharing Responsibility and Holding Responsible', p. 351.

${ }^{13}$ Duff, 'Blame, Moral Standing and the Legitimacy of the Criminal Trial', p. 137.

${ }^{14}$ Radzik, 'On the Virtue of Minding Our Own Business', p. 177.

${ }^{15}$ Smith, 'On Being and Holding Responsible', p. 478.

${ }^{16}$ Joseph Raz, 'On Respect, Authority and Neutrality', Etbics 120 (2010) p. 279. Raz points out that the term standing is rarely used in everyday life outside the law. I do not mean to deny this by referring to talk of standing. What I have in mind is discussion of standing in the philosophical literature.
} 
responsible is one in which we all frequently engage. Talk of (a lack of) standing is meant to help us better understand that practice, by capturing a distinctive kind of defect (or its absence) that figures in it. Until we work out what that defect is, our understanding remains deficient. Nor can we know if there is really one defect here or many. We cannot know if meddling and hypocrisy are problematic in the same-or a similar-way. And there is a further problem. It is far from clear that we can know what grounds a given defect until we know what kind of defect we are dealing with. Yet I already mentioned that many writers proceed to the question of grounds without first getting clear about what is being grounded. One might deny that this is problematic. But we would not try to determine the grounds on which people have (or lack) claim-rights without reference to the fact that such rights have correlative duties. Nor would we try to determine the grounds on which people have (or lack) practical authority, without reference to the fact that practical authority is a normative power. It may, of course, be that to have standing just is to have a claim-right, or to have practical authority. If this turns out to be the case, it might be clearer to give up on talk of standing altogether, and to simply refer to these more familiar ideas. Whether this is so, I am claiming, is precisely what needs to be determined. We need to work out what we are talking about when we talk about standing to hold others responsible. My aim in this paper is to make progress with this task.

A note on methodology before we proceed. Our aim is to better understand an idea that figures in a particular practice, and to thereby better understand the practice itself. I will assume that we improve our understanding of the idea by improving our understanding of how the idea figures in the practice. I will therefore rely on examples in which it is typically said that participants have or lack standing. It might be said that to proceed in this way is to assume that the practices we have are normatively defensible. It might be said, in other words, that I will assume that because we go around acting as if certain 
instances of holding responsible are somehow defective, those holdings really have the defects we take them to have. This is not the case. Assuming that standing talk does indeed refer to a single idea, there is some defect in which a lack of standing consists. While I use examples to help work out what kind of defect this is, it does not followand I do not assume- that the defect taken to be present in the examples actually is. Whether or not this is so is a matter for normative argument, the success of which-it should go without saying-depends on factors external to the practices we have. At the end of this paper, I consider some arguments one might give for the conclusion that meddlers and hypocrites lack standing. My reason for doing so at the end is one I have already given: we cannot know whether something is a good normative argument without knowing what is being argued for; we cannot know who has (and lacks) standing, and on what grounds, until we know what it is to have (and lack) standing.

Our interest is in cases in which one agent is held responsible for their conduct by another. I have already mentioned several ways-including blame and condemnationin which this is done. Some think it is possible to hold another responsible in these ways without communicating this fact to the person being held. We can grant that this is possible. Here, I am concerned only with cases in which communication does occur-in which we blame, criticise or condemn others to their face.

Let us say for short that A holds B responsible for X by doing Y. We know that if A lacks standing, A's holdings are defective in some way. We want to know in what way they are defective. We can make progress by noting that when we hold others responsible, our holdings can be defective because of facts of different kinds. Sometimes 
holdings are defective because of facts about B or X. Imagine Bob is condemned for stealing a watch that he did not steal. Bob might reasonably object to being blamed. In making this objection, Bob would be appealing to (1):

(1) Condemnation is defective if B is condemned for $\mathrm{X}$ and $\mathrm{X}$ is not something $\mathrm{B}$ did.

Now imagine instead that Bob is blamed for returning a watch he found to its owner. Let us assume that Bob did indeed return the watch. He also took reasonable steps to find out who the owner was, and returned the watch at the first reasonable opportunity. As his actions were entirely justified, Bob again might reasonably object to being blamed. In this case, Bob would appeal to (2):

(2) Blame is defective if B is blamed for X and X is not blameworthy.

Notice that in both these cases, whether the defect in question obtains does not depend on facts about $\mathrm{A} \cdot{ }^{17}$ It does not matter, for the purposes of (1) and (2), who is holding B responsible. In some cases, however, things are different. Consider (3) and (4):

(3) Criticism is defective if B is criticised by A for X but X is none of A's business.

(4) Calling to account is defective if B is called to account by A for X but (i) A has in the past done $\mathrm{X}$ herself, and (ii) A is unwilling to account for having herself done $\mathrm{X}$.

\footnotetext{
${ }^{17}$ Other, of course, than the fact that $\mathrm{A}$ is holding $\mathrm{B}$ responsible.
} 
In both these cases, whether the defect in question obtains does depend on who is doing the holding. Start with (3). Whether I am meddling in your business by holding you responsible for $\mathrm{X}$ depends on whether $\mathrm{X}$ is any business of mine. And whether something is my business depends in part on the relationships in which I stand. To borrow an example from Duff: 'If I regularly fail to buy my round for the friends with whom I drink, that is their business; but it is not...the business of the passing stranger who happens to hear about it. ${ }^{18}$ Now consider (4). Whether I am acting hypocritically depends on what I have done in the past, and on my willingness to account for it in the present. In Cohen's words, it depends 'the record and/or posture' of the holder. ${ }^{19}$ For the purposes of (3) and (4) then, unlike (1) and (2), it does matter who A is. It matters who it is that is holding $\mathrm{B}$ responsible.

Discussions of standing distinguish the defects mentioned in (1) and (2) from those mentioned in (3) and (4). Those whose holdings exhibit defects of the latter, rather than the former, kind are said to lack standing. ${ }^{20}$ This implies that the defect in which a lack of standing consists is a defect the existence of which depends on facts about A. Our standing to hold one another responsible is therefore personal in the following way: it is something that varies depending on who we are, including the relationships we occupy, and the things we have done in the past. It is obvious enough that when we are beld responsible the defectiveness (or otherwise) of the holding depends on facts about us. This is the effect of (1) and (2). The point here is that facts about us also matter when we are doing the holding. This is the effect (3) and (4). The result is that our practice of holding others responsible is sensitive to our distinctiveness as persons in two ways.

\footnotetext{
${ }^{18}$ Duff, 'Responsibility, Citizenship and Criminal Law', p. 133.

${ }^{19}$ Cohen, Finding Oneself, p. 121.

${ }^{20}$ See e.g. Cohen, Finding Oneself, p. 119; Duff, 'Relational Reasons and the Criminal Law', pp. 203-204.
} 
Those practices are sensitive to facts about us-facts that distinguish us from our fellows-not only when we are cast by others in the role of $\mathrm{B}$, but also when we cast ourselves in the role of A. It is in this latter sensitivity that our standing to hold others responsible consists. ${ }^{21}$

Other examples of standing talk help to bear out these claims. Take a case in which Bob is condemned by Alan for stealing a watch. Imagine Alan urged Bob to steal, and that this is in part why Bob stole. Several writers claim both that there is something defective about Alan's condemnation, and that Alan lacks standing to condemn. ${ }^{22}$ These writers accept (5):

(5): Condemnation is defective if B is condemned by A for X and A is complicit in $\mathrm{B}$ doing $\mathrm{X}$.

The defect mentioned in (5) is again personal to A-it exists in virtue of the fact that $\mathrm{A}$ aided, abetted or otherwise involved herself in $\mathrm{X}^{23}$

\footnotetext{
${ }^{21}$ Darwall is one writer who might be thought to deny this. He writes that 'as a representative of the moral community', 'anyone' has standing 'to blame the wrongdoer or to hold him responsible through (what Strawson called “impersonal") reactive attitudes such as indignation' (Darwall 'Authority and Reasons: Exclusionary and Second-Personal', p. 262) When he makes these claims, however, Darwall is not concerned with the communication of blame or indignation. He explicitly acknowledges that things may be different when it comes to blaming wrongdoers overtly: 'Even when blame and indignation are fitting responses, this does not necessarily mean that one has standing, for example, to blame someone to her face. How we should appropriately hold someone responsible is itself a complex normative question' (Stephen Darwall, 'Reply', Ethics 118 (2007), p. 62). It is that complex normative question in which I am interested here.

22 See e.g. Cohen, Finding Oneself, p. 125ff; Scanlon, Moral Dimensions, p. 177; Tadros, 'Poverty and Criminal Responsibility', pp. 398ff.

${ }^{23}$ Standing talk also figures in discussions of forgiveness. It is true, of course, that when A forgives B for $\mathrm{X}, \mathrm{A}$ does not hold $\mathrm{B}$ responsible. It may be closer to the truth to say that forgiveness releases $\mathrm{B}$ from responsibility rather than holding $\mathrm{B}$ to it. Be that as it may, it is widely claimed that only victims have the
} 
It is worth making one further point at this stage. Though I have claimed that A's standing depends on facts about $\mathrm{A}$, the language of dependence conceals two ways in which those facts matter to A's standing. Sometimes facts about A ground A's standing to hold B responsible. Such facts give A standing that A would not otherwise have. Consider again the case I earlier borrowed from Duff. It is in virtue of the relationship I have with my friends that I have standing to call them to account for failing to buy a round. By forming such relationships, I gain standing that mere strangers lack. Facts about A may, however, also play a second role. Those facts may defeat A's standing to hold B responsible. When such facts obtain, A loses standing A would have otherwise had. This is true of the facts that make A complicit in B's wrongdoing. All else being equal, B's friends have standing to call B to account for killing C. They lose that standing if they aid or abet B's killing.

The remarks in the previous paragraph leave open a number of possible positions. They leave open the possibility that, in some cases, grounds for standing are not required. Consider a case in which $\mathrm{X}$ is torture, $\mathrm{B}$ is the torturer, and $\mathrm{Y}$ is mild criticism. If $\mathrm{Y}$ is done to B, we may not need to know anything about $\mathrm{A}$ to know that—-defeaters aside- $\mathrm{A}$ has standing. This is consistent with saying that when $\mathrm{X}$ is more benign, and $\mathrm{Y}$ is more burdensome, grounds for standing are required. Imagine $\mathrm{X}$ is failure to turn up to class, $\mathrm{B}$ is the student who so failed, and Y is heavy criticism. It is plausible to think that for a stranger to do $\mathrm{Y}$ in such a case would be an instance of meddling. Things are different if standing to forgive (see e.g. Darwall, 'Authority and Reasons: Exclusionary and Second-Personal', p. 262; Jeffrie Murphy, Getting Even (Oxford: Oxford University Press, 2014) p. 13). If a stranger were to forgive Bob for assaulting Alan last week, this would, at best, be a defective act of forgiveness. The same would not be true if Alan did the forgiving. For present purposes, the point is this: just as standing to hold responsible is personal to the holder, so standing to forgive is personal to the forgiver. 
A is B's teacher, or a fellow member of B's class. These people have standing, it is plausible to think, in virtue of their relationship to B: they would not meddle by doing Y to $\mathrm{B}$ for $\mathrm{X}$.

These examples suggest that the standing each of us has varies along three dimensions. It varies with reference to who is being held responsible-with reference, that is, to B. As Duff's example shows us, those who form relationships with particular people gain standing that others lack. Standing also varies with reference to what we are holding B responsible for-with reference, that is, to X. I have standing to hold my students responsible for failing to submit essays, but not for failing to buy cards for their parents. Were I to do the latter, this would be another instance of meddling. Finally, our standing varies with reference to the way we hold others responsible-with reference, that is, to Y. Compare two cases in which students might hold one another responsible for failing to prepare for class. In the first, they do so by refusing to share notes with those who fail to prepare, and who offer no satisfactory explanation for the failure. In the second they do so by barring those who fail to prepare from the classroom until a satisfactory explanation is forthcoming. It seems clear that there is something defective about the second holding: students, we might plausibly say, do not have standing to bar one another from class. This suggests that we should add (6):

(6) Holdings are defective if B is held responsible for X by A but A has no business doing $\mathrm{Y}$ to $\mathrm{B}$ for $\mathrm{X}$.

This defect may obtain even if $\mathrm{X}$ is A's business. So (6) differs from (3). Whether the defect mentioned in (6) obtains again depends on facts about A. B's failure to prepare is the business of her classmates. But they lack standing to blame her by denying access to 
class. That I have this standing is a function of my role as teacher of the class. As before, the standing we each have_-as student and teacher—is personal to us.

The previous paragraphs might seem to suggest that when grounds for standing are required, those grounds always consist in some relationship between A and B. Though I have discussed cases of this kind, nothing I have said entails that relational facts are the only facts that can ground standing. Take the case of criminal punishment. It is often said that the punishments imposed by the criminal justice system-including terms of imprisonment and fines—are punishments that only courts (and perhaps other state institutions) have standing to impose. ${ }^{24}$ Private individuals who attempt to impose them are condemned as vigilantes. One explanation of this is relational. At least in democracies, it is claimed, state institutions are authorised to punish on behalf of the political community. Those punished are part (or guests) of that community. So there is a relationship between punisher and punished which grounds the courts' standing, and which is absent when the punisher is a private individual. ${ }^{25} \mathrm{~A}$ rival explanation is instrumental. At least where there are independent courts, staffed by well-trained lawyers and judges, reserving the imposition of punishment to those courts is likely to have various good effects. One is displacing acts of retaliation that might otherwise be taken by, or on behalf of, victims. ${ }^{26}$ Another is making it more likely that, where no relevant difference exists between wrongdoers, punishment will be doled out in equal amounts. A

\footnotetext{
${ }^{24}$ See e.g. Malcolm Thorburn, 'Two Conceptions of Equality before the (Criminal) Law', in F. TanguayRenaud and J. Stribopoulos (eds.), Retbinking Criminal Law Theory (Oxford: Hart Publishing, 2012), pp. 3-20; Duff, 'Relational Reasons and the Criminal Law', pp. 196ff; Postema, 'Politics is About the Grievance', pp. 293-323.

25 This kind of explanation is defended in Duff, 'Responsibility, Citizenship and Criminal Law'. There may, of course, be other relationships between private punishers and those they (propose to) punish. One question for defenders of the relational explanation is why these relationships cannot ground standing. ${ }^{26}$ John Gardner, Offences and Defences (Oxford: Oxford University Press, 2007), pp. 213-238.
} 
third is making it less likely that those who committed no crime will be punished at all. ${ }^{27}$ If facts like these give the courts their standing, that standing is not grounded in any relationship between punisher and punished. Much more would, of course, need to be said to vindicate either of these accounts. My interest here is not in which account should be preferred. The point here is simply this. While it is true that for A to have standing to hold $\mathrm{B}$ responsible is for $\mathrm{A}$ to stand in a kind of relationship with $\mathrm{B}$, it does not follow that facts about A's other relationships figure among the grounds of A's standing. ${ }^{28}$ The possibility that standing might be grounded instrumentally is enough to show that this is the case.

Let us now turn to two further questions. Whose normative position depends on the standing A has? How is that normative position so dependent? We know that if A lacks standing, A's holdings are afflicted by a defect that is personal to A. Answering these two questions will help us further clarify the affliction in question.

We are concerned with a defect that figures in our practice of holding one another responsible. One function the defect fulfills is providing a reason against defective holdings. Imagine Clare asks Alan why he has done nothing to criticise Barb for not buying Deborah a birthday card. Alan might reply that it is none of his business. Alternatively, he might say that any criticism he made would be hypocritical, as he

\footnotetext{
${ }^{27}$ Michael Moore, 'A Tale of Two Theories', Criminal Justice Ethics 28 (2009), p. 42.

${ }^{28}$ To borrow a phrase from John Gardner, we can accept that standing is conceptually relational, while denying that A's standing has a relational justification. See J Gardner, 'Relations of Responsibility' in R. Cruf, M. Kramer and M. Reiff, (eds.), Crime, Punishment and Responsibility (Oxford: Oxford University Press, 2012), p. 92.
} 
routinely fails to buy cards for Clare. We can leave open whether Alan is correct about what his business is, or about what counts as hypocrisy. The point is that if Alan were to make these claims, he would invoke his lack of standing as something that counts against him criticising Barb—as a reason not to hold her responsible.

Notice, however, that as well as taking a lack of standing to bear on our position qua holder, we also take it to bear in a particular way on the holdings of others. Imagine that Alan does criticise Barb for failing to buy a card for Deborah. Barb might reply that this is none of Alan's business, or that Alan is being hypocritical. And she might take this to suffice as a reply to Alan's criticism. I take for granted that exchanges of this kind are familiar to the reader. I take for granted, that is, that giving and receiving replies like Barb's is a fairly routine part of our practice of holding one another responsible. That this is so, I will claim, teaches us something important about standing. To explain why, I first need to say a little more about what it is to hold others responsible.

We can begin by noting that such holdings involve an implicit accusation. It is implicit in my calling you to account for some action that your action is one that must be accounted for. Now we do not need to account to anyone for having performed some action, unless that action is at least pro tanto wrong. I do not ordinarily need to account for taking a walk in a meadow at lunchtime. This is because there is ordinarily nothing even pro tanto wrong about that. Things are different if I take the walk when I had promised to take my daughter ice-skating, or if the meadow is private property that is not open to the public, or if I take the walk while I should be giving a lecture. Taking the walk would then be at 
least pro tanto wrong, and I would have something for which to account. ${ }^{29} \mathrm{My}$ aim here is not to reflect on the details of the examples. It is rather to draw attention to a point about what it is to call others to account, namely that if someone were to call me to account for taking a walk, they would implicitly accuse me of having committed a pro tanto wrong in taking it. Something even stronger is true in cases of criticism, condemnation or blame. To criticise someone for taking a walk is not just to accuse them of having done something that is wrong pro tanto. It is to accuse them of having done something that is wrong all things considered, because it was done without either justification or excuse. We can see this by noting the pressure one comes under to withdraw one's criticism if either a justification or an excuse comes to light. The same is true of blame and condemnation.

I have claimed that when we hold others responsible in the ways I have described, we implicitly accuse them of having done something that is at least pro tanto wrong. There are various ways of responding to such accusations. One is to deny the content of the accusation. One does this by denying that one did $\mathrm{X}$, or that $\mathrm{X}$ is even pro tanto wrong. Another way to respond is to accept the accusation's content, at least arguendo. In cases where one is called to account, one way to do this is to offer a justification or excuse. We do not need to justify or excuse doing $\mathrm{X}$ unless $\mathrm{X}$ is at least pro tanto wrong. This is why I do not ordinarily need to justify or excuse taking a walk in a meadow at lunchtime. If I do offer a justification or excuse for walking, I thereby accept (at least arguendo) that the walk was wrong pro tanto. So I accept the content of the accusation made against me. In cases of criticism, condemnation or blame, things are slightly different. In such cases, offering

\footnotetext{
${ }^{29}$ We can leave open here whether pro tanto wrongs are actions that always breach a duty, breach of which is sometimes justified, or actions that ordinarily breach a duty, but do not when a justification exists. For discussion of both views, see Gardner, Offences and Defences, pp. 77-89.
} 
a justification or excuse amounts to a denial not an acceptance, because one is accused of lacking something one now claims to have. There are, however, other ways to accept the accusations made in such cases. These include expressions of remorse, or acts of repentance, both of which concede (at least on their face) that one was neither justified nor excused in what one did.

To respond in either of the ways I have described is to engage with accusations on their merits: it is to accept or deny the content of the accusation with which one is faced. Those who merely respond by pointing to a lack of standing do nothing of the kind. In fact, they neither accept nor deny the content of the accusations made against them. They dismiss accusations without doing either of these things. We can see this by returning to the case in which Alan criticises Barb for failing to give a card to Deborah. If Barb replies by saying that this is none of Alan's business, or that Alan is being hypocritical, Barb takes no position on the content of Alan's criticism. She neither accepts nor denies (i) that she got a card, (ii) that not getting one was pro tanto wrong, or (iii) that she had a justification or excuse for the omission. If Barb takes this reply to suffice, Barb dismisses Alan's criticism without doing any of (i)-(iii). She dismisses it without reference to the merits of the accusation with which she is faced.

Call a response to an accusation content-sensitive if it accepts or denies that accusation's content. Call a response content-insensitive if it does neither of those things. I have claimed that to invoke another's lack of standing is to offer a response of the latter kind. One might ask what all this has to do with the questions raised at the beginning of this section. One might ask, that is, what it tells us about the difference (a lack of) standing makes to the normative situation. We can see the answer by noting another aspect of the practice that is our topic. As many others have observed, when A engages in that practice 
by holding $\mathrm{B}$ responsible for $\mathrm{X}, \mathrm{A}$ does not simply report that $\mathrm{B}$ has done $\mathrm{X}$. To hold someone responsible, in other words, is not merely to describe the state of the world as we see it. It is also to demand something from those who are held. Duff writes that calling others to answer involves 'demanding an explanation and, unless the explanation is exculpatory, an apology, ${ }^{30}$ Scanlon makes similar claims. ${ }^{31}$ And Smith writes that

\begin{abstract}
Moral criticism by its very nature seems to address a demand to its target. It calls upon the agent to explain or justify her activities in some area, and to acknowledge fault if such a justification cannot be provided. ${ }^{32}$
\end{abstract}

For all these writers, to hold another responsible for some act is to demand a contentsensitive response. ${ }^{33}$ To invoke a holder's lack of standing - and to thereby dismiss the holding - is to refuse to accede to this demand. It is to implicitly deny that a contentsensitive response is owed to A. ${ }^{34}$ It is true, of course, that we may be mistaken about the

\footnotetext{
${ }^{30}$ Duff, 'Blame, Moral Standing and the Legitimacy of the Criminal Trial', p. 123.

31 T.M. Scanlon, 'The Significance of Choice', in S. McMurrin (ed.), The Tanner Lectures on Human Values (Salt Lake City: University of Utah Press, 1988), p. 171; T.M. Scanlon, What We Owe to Each Other (Cambridge: Harvard University Press, 1998) p. 272.

32 Angela Smith, 'Control, Responsibility and Moral Assessment', Philosophical Studies 3 (2008), p. 381.

${ }^{33}$ To be clear, the claims being made here are not claims about the aims of individual holders. They are claims about what it is to hold someone responsible. A government that wishes to prevent wrongs might well try to do so by holding people responsible for wrongdoing. Alternatively, it might invest heavily in surveillance and then deport those it thinks are potential wrongdoers. Both methods might contribute to the achievement of the government's aims. But it is only governments that use the former method that attempt to prevent wrongs by accusing the governed of wrongdoing, and by demanding a content-sensitive response to their accusations.

${ }^{34}$ Why not think that it is simply a refusal to do what one has a duty to do? One reason not to think this is that our practice distinguishes between refusals to give content-sensitive replies to those who have and lack standing. All else being equal, if X is A's business, and B dismisses A's criticism of X without reference to its content, B's dismissal of A will itself be taken to be a pro tanto wrong. If B has no justification or excuse for the dismissal, A will be taken to be justified in criticising B for it. If, on the other hand, X is none of A's business, B's dismissal will not be taken to be wrong even pro tanto, and there will be no question of her
} 
standing others have. But the fact that a lack of standing is taken to license the aforementioned refusal tells us something important about the defect in which a lack of standing consists. It suggests that when we really do lack standing, we are not owed a content-sensitive response to our holdings. Because A is not owed a response of this kind, B need not consider which such response—which denial or acceptance—-she ought to offer. This is why the accusation implicit in A's holding can be dismissed without reference to the content it has.

If I am right to this point, A's standing bears on the normative position of $\mathrm{B}$ in the following way. If $\mathrm{A}$ lacks standing to hold $\mathrm{B}$ responsible, $\mathrm{B}$ has no duty to offer $\mathrm{A}$ the content-sensitive reply that A demands. Where A has standing, B has that duty. I mentioned earlier that a number of writers equate standing with authority. The above remarks explain why this equation is tempting. They suggest that to have standing to hold another responsible is to have a normative power. If A has standing, A has the power-by holding B responsible - to give B a duty to provide A with a contentsensitive response. ${ }^{35}$

Does it follow that standing and authority are one and the same? I do not think it does. To see why, notice that to have authority is not to have any old normative power. I have the power to give you a duty to stop by stepping out in front of your car. It does not

justifiably being criticised by A. Why not? Because B had no duty to give A the content-sensitive response she demanded.

${ }^{35}$ Raz queries whether, in the legal context, standing is a power: see Raz, 'On Respect, Authority and Neutrality', p. 293. He points out that where a court fails to notice that A lacks standing and proceeds to consider A's complaint, the court may be bound to continue to hear the case despite A's lack of standing. I am not sure that this example substantiates Raz's doubts. The example shows that where A lacks standing, the court's own actions may preclude dismissal of A's claim. But it does not show that those who lack standing can, simply by bringing a claim, put the court under a duty to give a content-sensitive response. It is such a power in which, I claim in the text, standing partly consists. 
follow that I have authority over you. To have authority is to have a power to create duties with two features. They are duties that (i) exist in virtue of one's communicating one's intention to create them $;^{36}$ and (ii) do not exist in virtue of the independent value of the actions they require one to perform. ${ }^{37}$ The first feature is often captured by the claim that if $\mathrm{A}$ has authority over $\mathrm{B}$, and directs $\mathrm{B}$ to do $\mathrm{Z}, \mathrm{B}$ has a duty to do $\mathrm{Z}$ that exists because $A$ said to do it. It is a mark of the second feature that authorities can create duties with a variety of different, even contradictory, contents—-duties to leave a place or stay in it, to undergo treatment or refrain, to rebuild factories or destroy them, and so on. ${ }^{38}$ In Hart's words, the actions B is required to perform may have 'nothing in common', because the requirements authority creates do not owe their existence to 'the nature or character of the actions to be done, ${ }^{39}$

These comments give us one reason to reject the equation of standing with authority. I have claimed both that to hold $\mathrm{B}$ responsible for $\mathrm{X}$ is to accuse $\mathrm{B}$ of doing $\mathrm{X}$, and that if A has standing, A's holding puts B under a duty to provide a content-sensitive reply. Not just any content-sensitive reply will do. All else being equal, if $\mathrm{X}$ is my business and I call to you to account for doing $\mathrm{X}$, it is not enough for you to invent some fantastical story about why you did X. What you owe me is the content-sensitive response that fits the facts - that explains what you in fact did and why you in fact did it. ${ }^{40}$ If this is right, to have standing is to have the power to impose a duty the content of which is entirely

${ }^{36}$ See e.g. Raz, 'On Respect, Authority and Neutrality', p. 292; David Enoch, 'Authority and ReasonGiving', Philosophy and Phenomenological Research 89 (2014), pp. 296-332.

${ }^{37}$ Independent, that is, of the exercise of authority. See e.g. H.L.A. Hart, Essays on Bentham (Oxford: Oxford University Press, 1982), pp. 254-255; Joseph Raz, The Morality of Freedom (Oxford: Oxford University Press, 1986) p. 35.

${ }^{38}$ Raz, The Morality of Freedom, p. 35.

${ }^{39}$ Hart, Essays on Bentham, p. 254.

40 And if you have no adequate explanation, the response-be it remorse, repentance, apology, etc—called for by your wrongdoing. 
specific. That one has this power does nothing to suggest that one also has the power to impose duties with a variety of other contents (such as a duty to invent a fantastical story, or to give no response at all).

One might ask why anyone should have the former power without having the latter. The obvious answer is that fitting content-sensitive responses are responses we have independently existing reasons to provide-independent, that is, of the fact that we have been held responsible. Imagine that, having broken A's arm, B seeks out A to explain that this was the only way to save C's life. We would not think this something B had no reason to do. That reason might exist because of the interest A has in receiving B's explanation. Or it might exist because of the interest $\mathrm{B}$ has, as a rational being, in explaining why she acted as she did. ${ }^{41}$ It might be a bit of both. The point here is this: that there is independent value in giving a content-sensitive response that fits the facts helps explain why those with standing have the power to demand that response in particular. We already saw that things are different when it comes to authority. A's authority over B consists in A's power to give B duties that exist because of A's say-so, not because of the independent value in doing what A requires B to do. If I am right, A's standing to hold $\mathrm{B}$ responsible is not like this. Her standing consists in a power to require $\mathrm{B}$ to respond as befits the facts, at least partly because so responding is of independent value. ${ }^{42}$

I mentioned earlier that according to some writers to have standing is to have a right.

\footnotetext{
${ }^{41}$ For an argument that we have such an interest, see Gardner, Offences and Defences, pp. 177-200.

42 One might claim that authority can exist in the absence of the second feature identified in the text. Even if the second feature is typically present, perhaps only the first is required: A has authority over B whenever A has the power to impose duties on B by communicating an intention to create those duties. If this is right, standing is a particular-perhaps atypical—instance of authority. It remains the case that we should not equate the two. That one thing is an instance of another does not make them one and the same.
} 
The above remarks might seem to offer some support for that thesis. Consider again a case in which A has standing to call B to account for X. One might think that A has the following claim-right: the right to an explanation of why B acted as B did, which explanation B has a correlative duty to provide to A. Notice that if we accept this picture, standing is no mere power. It is not merely the case—on the picture in question-that A can put $\mathrm{B}$ under a duty by holding $\mathrm{B}$ responsible. Rather, this duty is one $\mathrm{B}$ has, whenever A has standing, even if A never holds B responsible at all. It is precisely in order to conform to the duty correlative to B's right, that B might seek out A—even if A demands nothing of her-to give her reasons for breaking A's arm.

Whatever appeal this picture has, it is not one we should accept. We need not deny that the aforementioned right is possessed by some of those who have standing. The most obvious such people are those who have been wronged by B. It would be a mistake, however, to assume that all cases of standing are like this. For one thing, we often have standing to hold people responsible for things they have not done. Imagine that one of my students—B_-submits her essay for class. I mislay B's work and call her to account for (what I take to be) a failure to submit. I thereby accuse B of having acted wrongly. In this case, the content-sensitive response that fits the facts is a denial. All else being equal, it seems clear that B could not simply refuse to offer this reply. She could not respond that submission was none of my business, or that I otherwise lack standing. Absent some defeater, she has a duty to respond to my accusation by providing the denial. But it also seems clear that B would have had no such duty had I not held her responsible (at least if she had no reason to think the essay had gone astray). Had I said nothing, B would have had no duty to explain her conduct to me. This is enough, I think, to show that standing does not consist in the aforementioned claim-right. And it is further support for the view that those who have standing have a normative power: the power, by holding $\mathrm{B}$ 
responsible, to put $\mathrm{B}$ under a duty to provide a fitting content-sensitive reply. ${ }^{43}$

The last section focused on the way in which A's standing to hold B responsible bears on B's reasons for action. I claimed that if A lacks standing, B lacks a duty to give A the content-sensitive reply that A demands. I earlier pointed out that A's standing also bears on A's own reasons for action. The fact that $\mathrm{X}$ is not our business is a fact that counts against our holding B responsible for X. The same goes for the fact that A's holding would be hypocritical. What does this show? One suggestion is that it shows that it is wrong to do what one lacks standing to do. This, however, is ambiguous. When we say that $\mathrm{A}$ acted wrongly, we may mean that $\mathrm{A}$ acted in breach of a duty. Or we may mean that the act was one A ought not to have performed. It is not always the case that we ought not to do what we have a duty not to do: though I have a duty not to invade your privacy, I am justified in breaching that duty if this is necessary to save five lives. Let us say that acts I ought not to perform are impermissible. If A lacks standing to hold B responsible, does it follow that A's holding B responsible is impermissible? Cohen explains why it does not:

\footnotetext{
${ }^{43}$ One might say that to have standing is to have a conditional claim-right: the right to a fitting contentsensitive reply from B if A opts to hold B responsible. What we should make of this proposal depends on what view we should take about rights. Consider the interest theory. This theory implies that $\mathrm{A}$ has a conditional claim-right if and only if A's ability to put B under a duty is grounded in A's interests. Notice, however, that A's standing to hold B responsible is not always grounded in interests of A. The standing of teachers to hold their students responsible is grounded in the interests of students. The standing of courts to call criminals to account is grounded in the interests of victims, or of the community as a whole. There are many other examples.
} 
I believe that lying is in itself wrong, and that it therefore counts against an act that it is a lie, which is to say that there is something wrong with lying because of its nature, whatever its typical, or unusual-case, consequences may be. But sometimes those consequences can make it all right, or even imperative, to lie. So, similarly, here: I believe that there is something wrong with condemning unless certain presuppositions are fulfilled, but if dodgy condemning is going to save the children, then I say: 'Condemn away!' ... I think one can say: 'He has no right to condemn, but let us hope he does condemn', and maybe even 'but he ought to do so...'44

The presuppositions Cohen mentions are the conditions one must satisfy to avoid the defects mentioned in (4) and (5). Cohen suggests that condemning B in violation of these conditions is 'wrong', and something the condemner has 'no right' to do. When he says these things Cohen could not mean that such condemnation is impermissible. An act cannot be impermissible while also being 'all right' or 'imperative', and Cohen's view is that condemnation which violates the conditions in (4) and (5) can be both these things. Cohen could, however, mean that those who condemn in this way are in breach of a duty. I already mentioned that one may breach a duty and still be justified in doing what one does. Cohen thinks that those who violate the conditions in (4) and (5) are sometimes justified in violating them and that they do something 'wrong', or something they have 'no right' to do. These claims are compatible if 'wrong' means 'breach of duty' and if 'right' means 'privilege'. To lack a privilege to condemn just is to have a duty not to condemn. Cohen might thus be understood to be making the following claims: those who lack standing to hold others responsible have a duty not to so hold them; but they do not always act impermissibly in doing so.

${ }^{44}$ Cohen, Finding Oneself in the Other, p. 120. 
Though Cohen is concerned with (4) and (5), his claims also apply to (3). One can say (and be right): 'It's none of her business, but let us hope she does condemn', and maybe even 'but she ought to do so...' This last claim might be denied, so it is worth pausing briefly to defend it. It is true, of course, that if I condemn you for X, the implication is that, as far as I am concerned, $\mathrm{X}$ is my business. Were I to say: 'It's none of my business, but...' and then proceed to condemn you all the same, you might rightly accuse me of pragmatic self-contradiction. It may then seem a short step to the conclusion that the cases in which I am justified in condemning you for $\mathrm{X}$ just are the cases in which $\mathrm{X}$ is my business. If this conclusion were correct, one could not violate (3) and still be justified in doing what one does. In this respect, (3) would be unlike (4) and (5).

The seemingly short step, however, is unwarranted. To see why, notice that when we condemn others, this ordinarily implies that we have made an adverse judgment about them. ${ }^{45}$ And this in turn implies that we have taken it upon ourselves to inquire into a particular episode in their lives, in order to work out whether their conduct indeed warrants such a judgment—it implies, in short, that we have made that particular episode our business. Doesn't it follow that we are only justified in condemning people for conduct that is our business? It does not. Though I have described the ordinary implications of acts of condemnation, it is possible to cancel those implications. One way to do this is for the condemner to deny that her condemnation was motivated by an adverse judgment about the condemned. Were I to say: 'Your love life is none of my business, and I make no adverse judgment about it, but it was necessary to condemn your new relationship to talk your ex-husband down from the ledge', there would, I think, be nothing self-contradictory about my utterance. It is true that, were I to say all this at the

\footnotetext{
45 To condemn $\mathrm{B}$, as we saw above, is to accuse of having acted without justification or excuse.
} 
time of the condemnation, it is far from clear that my utterance would condemn at all. ${ }^{46}$ It is also likely that my life-saving aims would not be achieved. This suggests that there is something insincere about condemning someone for something one knows is not one's business, at least when one's reasons for the condemnation are of the type I have described. But none of this shows that such condemnation is always impermissible. Could it really be said that if my condemnation proved necessary to talk your ex-husband down, I ought not to have condemned you? This, it seems to me, is hard to believe.

Our concern is with the bearing of A's standing on A's reasons for action. The above remarks suggest the following possibility. Those who lack standing are those whose holdings breach certain duties, including duties not to meddle in others' affairs, not to act hypocritically, and not to hold others responsible for conduct in which one is complicit. What binds all these duties together is that they are agent-relative: whether A violates any of them in a given case depends on facts about $\mathrm{A} .{ }^{47}$ Those who lack standing to hold B responsible are those who have agent-relative duties not to do the holding. ${ }^{48}$ To have standing, on the other hand, is to have a particular type of privilege-it is to lack agentrelative duties not to hold $\mathrm{B}$ responsible for $\mathrm{X}$ by doing $\mathrm{Y}$. Let us call the privilege in question an agent-relative privilege.

\footnotetext{
${ }^{46}$ Because it is far from clear that I would in fact be making an accusation or a demand.

${ }^{47}$ Other, of course, than the fact that $\mathrm{A}$ is holding $\mathrm{B}$ responsible.

${ }^{48} \mathrm{I}$ mentioned earlier that some writers claim that standing is a right. This may be encouraged by the thought that the duties associated with standing can be waived. Imagine X is none of A's business. A has an agent-relative duty not to hold B responsible for X. But it is plausible to think that B can waive this duty, so that A no longer acts wrongly by holding B responsible. Not all cases of standing, however, have this feature. To see why, notice that an agent's lack of standing is sometimes grounded in the interests of us all. In English law, for instance, the state lacks standing to try defendants whose presence in the jurisdiction was obtained by the past misconduct of state officials: exp Bennett (1994) 98 Cr App Rep 114. This duty is agent-relative: it is inapplicable to trials conducted by agents not implicated in the state's misconduct. More importantly, the duty is grounded in the interest we all share in deterring misconduct of the relevant kind. Because it is so grounded, it is not a duty that the individual being held responsible can waive.
} 
If I am right, those who lack standing to hold others responsible need not act impermissibly in doing so. They may be justified in violating the agent-relative duties they have. We can now add that those who have standing need not act permissibly. One reason for this is that not all duties are agent-relative duties. We have duties not to condemn others for things they did not do, or that they were justified in doing. Whether A violates these duties in a given case does not depend on facts about $A$. They are, we might say, agent-neutral. Standing does not preclude violation of such duties. Whether my students submit their essays is my business. Defeaters aside, I have standing to call them to account for failing to submit. But if Barb submits, it would be wrong for me to criticise Barb for not doing so. Unless I have a justification or excuse, this would be impermissible.

These comments suggest another reason to reject the equation of standing with authority. We saw that to have authority is to have a particular type of normative power- the power to impose duties on others simply by communicating an intention to impose them. If A lacks this power, A lacks authority. I just claimed that those who lack standing lack a privilege. If A lacks a privilege to do Y, A has a duty not to do Y. Now it does not follow from the fact that A lacks a power to change B's normative position by doing $\mathrm{Y}$, that A has a duty not to do Y. I do not have the power to change your normative position simply by scratching my nose. It does not follow that I have a duty not to scratch it. Conversely, it does not follow from the fact that A has a power to change B's normative position by doing $\mathrm{Y}$, that A lacks a duty not to do Y. In many sports, the referee has a duty to correctly apply the rules of the game. But she nonetheless has a power to impose duties on the players by making decisions that are 
incorrect. The mistakenly awarded penalty is an obvious case. ${ }^{49}$ So there can be privileges without powers, and powers without privileges. It is the latter phenomenon that is important here. As the referee example shows us, that we have authority over others does not entail that we have a privilege to exercise it. But we do not have standing, I have argued, unless a privilege is what we have. If this is right, authority and standing are not one and the same.

We can now combine the analysis of this section with that of the last. Putting the two together gives us $(\mathrm{S})$ :

(S): A has standing to hold $\mathrm{B}$ responsible for $\mathrm{X}$ by doing $\mathrm{Y}$ if and only if $\mathrm{A}$ has both:

(i) An agent-relative privilege to hold B responsible;

(ii) The power to put B under a duty—by holding B responsible— to offer a fitting content-sensitive reply to A.

If I am right, those who wish to argue that certain holders lack standing must explain why those holders should lack (i) and (ii). I turn to arguments of this kind in the following section.

IV

Why should matters of standing figure in our practice of holding one another responsible? I mentioned earlier that this contributes to our distinctiveness as persons. It

\footnotetext{
${ }^{49}$ Similarly, a court that orders $\mathrm{D}$ to pay damages imposes a duty to pay on $\mathrm{D}$. The order may be a valid exercise of the court's powers-it may be binding on D-even if the court breached a duty in issuing it (because, say, the order violated the rules of precedent). As Hart puts the point, finality is not infallibility: see H.L.A. Hart, The Concept of Law, 3 $3^{\text {rd }}$ edn (Oxford: Oxford University Press, 2012), pp. $141 \mathrm{ff}$.
} 
makes our practices sensitive to facts about us_facts that distinguish us from our fellows-not only when we are cast by others in the role of $\mathrm{B}$, but also when we cast ourselves in the role of A. But we can still ask why we should want practices that are sensitive to such facts. If we shouldn't, the best thing to do might be to revise those practices.

I have focused on two cases - those of meddling and hypocrisy-in which holders are taken to lack standing. At first sight, it is not at all clear that either of these aspects of our practice should be retained. Consider two implications of holding that hypocrites and meddlers lack standing. First, we sometimes have duties not to make accusations thatconsidered in and of themselves-are unimpeachable. My criticism may be entirely accurate, proportionately expressed, and likely to help forestall similar wrongdoing in the future. Yet some fact about me may nonetheless give me a duty not to criticise. Second, others can dismiss our accusations-without doing anything to challenge their accuracy — simply by pointing to facts about our relationships and past conduct. As Radzik points out, there is something oddly 'legalistic' about this kind of dismissal: about pointing to the qualifications of one's accuser to dismiss the content of her accusation. ${ }^{50}$ Any defence of the claim that meddlers or hypocrites lack standing must be a defence of this legalistic reply-it must explain why, as I put it earlier, no content-sensitive reply is owed to A.

Now that we know what it is to have and lack standing, we are in a position to ask how all this might be defended. Consider first the case of meddling. We know that what

\footnotetext{
${ }^{50}$ Radzik, 'On the Virtue of Minding Our Own Business', pp. 177-178. Radzik discusses various reasons why it might be virtuous to mind one's own business. My interest here is in why not everything should be our business in the first place.
} 
counts as meddling depends on what counts as my business. I claimed earlier that whether $\mathrm{X}$ is my business depends at least in part on the relationships in which I stand. To return to Duff's example, that I never buy a round is the business of the friends with whom I drink. It is no business of a passing stranger. So she lacks standing to hold me responsible for it.

One explanation of all this is instrumental. Imagine a world in which all our actions were everyone's business. All else being equal, anyone would be able to put us under a duty to justify or excuse pro tanto wrongs-whatever they may be-and to express remorse and/or repent where we cannot do so. Mere strangers would be able to give us these duties simply by holding us responsible. Nor, if the accusations were accurate and proportionately expressed, would these holdings breach any duty. It seems clear that in this world, social relations would be far more onerous. To interact with strangers would be to take an increased risk of having to expose parts of one's life one would prefer to remain private, both because one would more often be duty-bound to explain oneself to others, and because others would more often lack a duty not to demand the explanation. Faced with all this, we might well choose not to take the risk. Fruitful interaction of innumerable kinds would then suffer accordingly.

There is no doubt something to be said for this instrumental story. But there is, I think, a deeper explanation of why meddlers should lack standing. Consider again the fact that what counts as our business depends on the relationships in which we stand. It is a truism that we have a measure of control over what those relationships are-over their character, intensity and duration. As we exercise that control, what counts as our business - and what counts as the business of others-expands and contracts. Take the case of friendship. To make friends is for parts of our friends' lives to become our 
business, and for parts of our lives to become theirs. To lose friends is for something like the opposite to happen. The same is true of becoming (and ceasing to be) a student, teacher, colleague or teammate. We have seen that—all else being equal—if some act of mine is your business, I owe you a content-sensitive response if you hold me responsible for the act: I must respond in a way that accepts or denies the content of your accusation; I must not dismiss it without doing either of these things. If my act is none of your business, I have no such duty. What's more, you have a duty not to hold me responsible for my act.

Now it follows from all this that as we form personal relationships we change our normative situation in the following way. We make it the case that we can demand things of one another without acting wrongly, and that we must accede to one another's demands to avoid acting wrongly ourselves. We bind ourselves together as people whoacross a range of cases-owe one another justification and excuse, remorse and repentance, when these responses fit the facts. This is not something we owe-at least not in the same range of cases - to others with whom we come into contact: to those who are not our friends, students, teachers, colleagues or teammates. Entering such relationships is thus a way of sharing one's life with other people—of opening parts of one's life to others that are not similarly open to all, and of gaining access to parts of others' lives that not all have. ${ }^{51}$ That we have some control over all this-over what we share with whom-augments the control we have over the shape of our own lives. All this would be lost in a world in which everything was everyone's business. Because the relevant normative situation would be one in which we stood with everyone, we could not choose to stand in it with some people alone. So we could not choose to share our lives with them in the way I have described. That we could not do this in a world in

\footnotetext{
${ }^{51}$ For related thoughts, see Williams, 'Sharing Responsibility and Holding Responsible'.
} 
which meddlers did not lack standing is a powerful reason for us not to live in that world.

I have claimed that the reason not everything is our business is that we would lose something of value if it were. It is precisely because some things are not everyone's business that we can make some things the business of our friends, colleagues, students and teammates in particular, and thereby share our lives with them in ways we do not share them with others. Relationships of this kind are often said to be a key constituent of our well being. It is no overstatement to say that those relationships could not existat least as we know them-were it not possible to open our lives up to particular people, while gaining access to theirs, in the way described above. We could not do this if meddlers did not lack standing. Our well-being would be correspondingly reduced.

The above remarks focus on the standing we have in our personal lives. One might wonder what implications my account has for the world of politics. Many think that some things are not the state's business. They think that the state sometimes meddles just like the rest of us. One explanation of this is continuous with the one I have offered. According to that explanation, one of the valuable relationships in which we stand is our relationship to one another as members of a political community. The state's proper task, as Duff puts it, is to be the 'institutional manifestation' of that community. ${ }^{52} \mathrm{By}$ participating in public life, we together determine what the political community's values are to be, and thereby determine what counts as the business of the state. If everything were the state's business, this is something we could not do. We would be deprived of the valuable relationship I just described.

\footnotetext{
52 Antony Duff, Answering for Crime (Oxford: Hart Publishing, 2007), p. 49.
} 
Whether this is an attractive explanation depends on what one thinks of the picture of the state on which it draws. On a rival view, the state's proper task is not to give effect to the values of any particular community. It is rather to help people lead better lives, including by protecting them against communities_-including political communitiesthat have become spiteful, petty, hateful or otherwise morally obnoxious. On this view, we need a different explanation of why some things should not be the state's business. One possibility returns us to the more personal relationships I already described. As many have claimed, the tools the state has at its disposal make its interventions heavyhanded and prone to error. ${ }^{53} \mathrm{~A}$ state that treated all aspects of our lives as its business would be likely to do a great deal of harm using those tools. It would be likely to both aggravate and misidentify disputes between friends, colleagues and teammates that would be better resolved by the disputants themselves. That this is so helps explain why the state should sometimes — though by no means always - tolerate wrongs that friends, colleagues and teammates commit. It helps explain why some parts of our lives should be none of the state's business.

Let us now turn to hypocrisy. According to (4):

(4) Calling to account is defective if B is called to account by A for X but (i) A has in the past done $\mathrm{X}$ herself, and (ii) A is unwilling to account for having herself done $\mathrm{X}$.

Wallace argues that (ii) is critical to the explanation of why hypocrites lack standing. Recall the case in which Bob is called to account by Alan for stealing a watch. If Alan is a

\footnotetext{
${ }_{53}$ Two classic treatments are J.S. Mill, On Liberty (London: J.W. Parker and Son, 1859); Joseph Raz, The Morality of Freedom, pp. 400-429.
} 
serial watch thief, and unwilling to account for his thefts, Alan demands from Bob something Alan refuses to give to other people. In doing so, Wallace claims, Alan elevates his own interests—both in getting answers, and in avoiding having to answerabove those of others. ${ }^{54}$ So there is a kind of inequality to which hypocrisy gives rise. This is why hypocrites lack standing.

Wallace's aim is to explain why hypocrisy is wrong. I have argued that if A lacks standing to hold $\mathrm{B}$ responsible, A's holding can also be dismissed by B. It can be dismissed because B lacks a duty to accede to the demands A makes, including demands to account for pro tanto wrongs when called to account for them. Now it is far from clear, it seems to me, why this should be the upshot of hypocrisy. Because of (ii), cases of hypocrisy are cases in which there is an existing moral deficit: that $\mathrm{A}$ has not accounted for $\mathrm{X}$ is itself a matter for regret. For the reasons just given, A's lack of standing appears to make it more likely that another deficit will be added to the mix - that B will not account for $\mathrm{X}$ either. ${ }^{55}$ In the case of theft with which we began, Alan's lack of standing appears to make it more likely that both Alan and Bob's thefts will go unaccounted for. What is unclear is why morality should level down in this way. We have already seen that there is value in our accounting for pro tanto wrongs. We need an explanation of why morality would respond to the fact that this value has not been achieved in some cases, by reducing the probability that it will be achieved in others.

Here is one reply to this challenge. We know that to hold another responsible is to make both accusations and demands. In cases of calling to account, it is to accuse others of

\footnotetext{
${ }^{54}$ Wallace, 'Hypocrisy, Moral Address and the Equal Standing of Persons', pp. 328-330.

${ }^{55}$ Because it allows B to dismiss A's demand for an explanation. True, others have may standing even though A does not. But A may be the only one likely to hold B responsible. This might be the case because (say) A is the only one harmed by B's conduct.
} 
doing something that must be accounted for, and to demand an accounting. There are risks to the holder in doing all this. Others may react badly to accusations made about them, particularly if they turn out to be misguided. Relationships may be damaged as a result. When we proceed to do the holding despite all this, it is plausible to think that we have a reasonably strong desire for what we demand. That hypocrites lack standing makes it the case that they are unlikely to get what they want until they account for similar wrongs they have committed. So it makes it more likely that this is what will happen: that the existing moral deficit will be made up. And if it is-if, that is, Alan accounts for the thefts he committed-it is more likely that our would-be hypocrite will get what he wants too- that Bob will account for his theft to Alan. So it is more likely that both Alan and Bob's thefts will be accounted for. This is the case precisely because hypocrites lack standing. ${ }^{56}$ I suggested above that in the case of hypocrisy, the defect we are dealing with looks like an instance of levelling down—of compounding a moral deficit that exists already. What we now see is that it is in fact the opposite. The fact that hypocrites lack standing — that their holdings are in this way defective-is morality's way of trying to level up..$^{57}$

Section IV offered some thoughts about why hypocrites and meddlers should lack

\footnotetext{
${ }^{56}$ If Alan had standing, Bob could not dismiss his demands, and Alan's incentive to account for his own thefts would be eliminated.

${ }^{57}$ We can see the point more clearly by thinking about our everyday experience of personal relationships. Imagine Clare and Deborah are friends. Clare comes to recognise she is upset with Deborah for what Clare perceives to be Deborah's bad behaviour. Clare thinks it is important to put this accusation to her friend. But Clare also realises that she has in the past behaved in a similar fashion. This realisation puts Clare under pressure to preface her accusation with an account of her own behaviour. The pressure exists precisely because Clare lacks standing. The pressure to account makes it more likely that this is what Clare will do, so it makes it more likely that the pre-existing moral deficit will be made up.
} 
standing. Those thoughts amount to a sketch of arguments that deserve further development. The sketch I have offered should, however, serve to vindicate a claim I have repeatedly made: that we cannot know who has (and lacks) standing, and on what grounds, until we know what it is to have (and lack) standing. Earlier, I quoted Raz's observation that 'we do not have an unproblematic grasp of the phenomena referred to' by standing talk. My primary aim here was to improve that grasp. I did so by defending — across sections I-III—the account of standing that I called (S). If am right, standing cannot be reduced to authority, permissibility or other familiar notions. This suggests that matters of standing have an autonomous role in our practice of holding one another responsible. If the sketch offered in section IV turns out to be accurate, there are at least some cases in which this aspect of our practice should not be relinquished. 